\title{
Buoyancy-Driven Ventilation Generated by the Double-Skin Façade of a High-Rise Building in Tropical Climate: Case Study Bandung, Indonesia
}

\author{
Akhlish Diinal Aziiz ${ }^{1}$, Mochamad Donny Koerniawan ${ }^{2}$, Suhendri $^{3}$ \\ 1,2,3 School of Architecture, Planning and Policy Development, Institut Teknologi Bandung, Jalan \\ Ganesha 10, Bandung
}

\begin{abstract}
High-rise buildings in tropical region is identical to the use of mechanical Air Conditioning in massive scale. Nevertheless, there is an encouragement to high-rise buildings to reduce its energy consumptions, since they consume quite large amount of energy. This challenge can be overcome with various of strategies, one of them, by means of reducing the cooling load of mechanical Air Conditioning in high-rise building. Prospects come from the modern tall building design strategies, for example the use of double-skin façade to give addition of building skin which could provide indoor temperature protection from outside. Doubleskin façade system has continued to increase in buildings in a tropical region such as in Indonesia. However, there is another potential of double skin façade, which is the possibility to increase the buoyancy effect in the air gap between the skin and building envelope. The possibility needs to be studied in order to give a proper way in designing double-skin façade of a high-rise building, especially on Bandung-Indonesia tropical climate. This paper explores the potential of double-skin façade in driving the air inside the façade to generate natural ventilation for a high-rise building in Bandung climate condition. Two parameters are used in exploring the buoyancy force, the width of double-skin façade and the temperature of the skin façade. In general, double-skin façade of a high-rise building in tropical climate can generate buoyancy driven ventilation for the building, it relates strongly to the distance between of the double-skin façade and the building envelope.
\end{abstract}

\section{Introduction}

Double skin façade system was introduced in Germany in late $18 \mathrm{~s}$ in factories building in subtropical area. The double skin façade system provided a warmer temperature inside the building when winter and cooler temperature when summer time [1]. This system commonly consists two layers of glasses as a curtain wall to help light intensity come through into the building, that this strategy worked well to decreasing of artificial light consumption, as a main aim is to dynamically respond the temperature outside of the building (Boake, Harrison, Collins, Chatham, \& Lee, 2003) [2] [3]. On the previous research, "Variable Analysis on Cause Factors of Glass Material Using in Designing

\footnotetext{
* Corresponding author: akhlishda@gmail.com
} 
Building" which involved hundreds of respondents also shows that glass material for façade could do the same in Indonesia tropical context [4]. The study informs the tendency of the market in Indonesia to use this material is increasing over the time. However, the fact is that Indonesia has a big amount of sun light through the year. Therefore, the strategy to design double skin façade need to be on certain, research states that the risk of using this system is higher than on the other region [5]

Generally, double skin facade is designed to control indoor temperature from extreme outdoor temperature which could decrease comfort level of user inside. Darmayanty [3] also called this system as envelope that creates some particular space to protect the building. This system also works as curtain wall still to let the natural light come inside, which is one of the reasons this system is often to use in high-rise building [4].

Kraagh (2000) in Poirazis [5] defined double skin façade as system which consists of two skin of building that separated by a gap to reduce heat transfer into the building. Boake (2003) also explaining that this gap has the potential to trap the heat from outside of the building and push out before it could enter the building. The gap between double skin façade system is generally called by air gap, or cavity gap. This part is one of the main parts which define how far your system could control the temperature indoor. Gratia, and De Harde also Lou, Huang (2012) in Barbosa [6] clearly shows that the temperature surface in the system could define the temperature inside the building. Another research done by Iyati [7] in 2012, using Computational Fluid Design (CFD) describe that glass material as façade of the building could be cooled by using air velocity, the more faster the velocity that the surface could get, the more it would be cooler.

This research is trying to get a result by exploring the width of the air gap in Double Skin Façade that could define the temperature of the surface (skin), which that could define the comfort level by also testing the surface temperature of the skin. The model of prototype also created to have the better accurate result, the simulation CFD using ANSYS is added to gain more completed result about how we design air gap in Double Skin Façade system to control temperature inside of the building in specific site.

\section{Methodology}

This is a quantitative study that utilise computational fluid dynamics to simulate air flow inside the double skin façade. Air flows generated in the space between the double skin façade and the exterior wall of the building is modelled and simulated in ANSYS Fluent. The prototype of the double skin façade is shown by Figure 1. The façade receives heat flux from radiation as much as $200 \mathrm{~W} / \mathrm{m} 2$. Initial air temperature is $27^{\circ} \mathrm{C}$, which the same as surface temperature of the surrounding walls. Inlet is set from the bottom of the model, and the 4 outlets, with $15 \mathrm{~cm} \times 15 \mathrm{~cm}$ area, are placed on top of it. Simulation is done for four cases, which characterised by the distance of the secondary skin from the primary façade. The distances are $0.3 \mathrm{~m}, 0.5 \mathrm{~m}, 1.0 \mathrm{~m}$, and $1.5 \mathrm{~m}$.
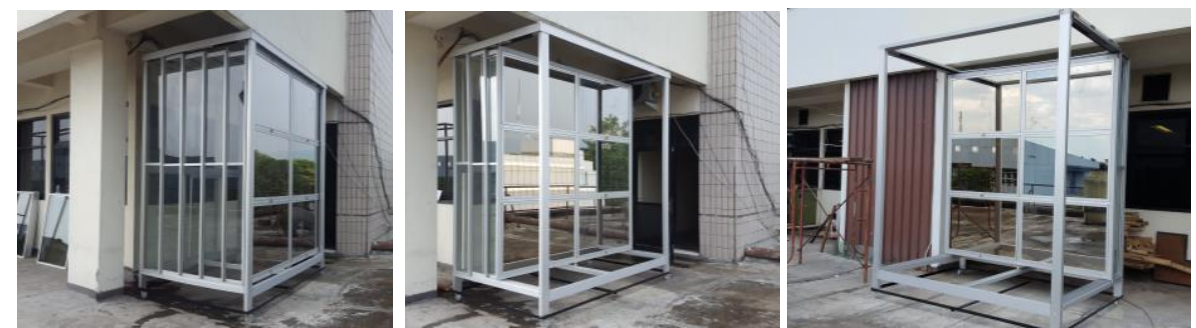

Fig. 1. Prototype of the Double Skin Façade. It designed to adjust the air gap so that could do the test in various width 
Along with the simulation, a calculation is also done particularly to the temperatureincrease rate inside the double skin façade. From the Eq. 1, a formula to calculate the temperature increase rate that will happen inside the double skin façade for the four cases can be derived. By modifying Eq. 1 as written in Eq. 2, a known variable appears, because $\mathrm{Q}$ over $\mathrm{t}$ is the heat flux to the space inside the double skin façade. Thus, the temperatureincrease rate formula can be derived as Eq. 3. This calculation is later useful in helping the understanding of heat removal rate by the double skin façade strategy.

$$
\begin{aligned}
Q & =m c \Delta T \\
\frac{Q}{t} & =\frac{m c \Delta T}{t} \\
\frac{\Delta T}{t} & =\frac{Q}{(\rho V) c t} \\
\frac{\Delta T}{t} & =\frac{1}{\rho c d} \frac{Q}{A t} \\
\frac{\Delta T}{t} & =\frac{\Phi}{\rho c d}
\end{aligned}
$$

Q : heat flows to a closed-system, in this case to the space inside the double skin facade ( $\mathrm{J})$

$\mathrm{m}$ : mass of the air inside the double skin facade $(\mathrm{kg})$

c : specific heat capacity of the air (Joule/kg.K)

$\Delta \mathrm{T}$ : temperature difference, in this case it will always increase because there is only heat gain) $(\mathrm{K})$

$\rho \quad$ : air density $(\mathrm{kg} / \mathrm{m} 3)$

$\mathrm{V}$ : Volume of the space in the double skin façade (m3), can be substituted by area of the façade (A) times its width (d)

$\Phi$ : Heat flux, number of heat flows in a second per unit area $(\mathrm{W} / \mathrm{m} 2)$

$\Delta \mathrm{T} / \mathrm{t}$ : Temperature-increase rate $(\mathrm{K} / \mathrm{s})$

In terms of simulation results, there are three parameters taken from it, wind velocity, volume flow rate, and temperature. Data for wind velocity are taken at the top outlets and average inside the double skin façade. Meanwhile, for the volume flow rate, the data are recorded from the top outlets. Also, for the temperature data, average temperature inside the double skin façade and the average surface temperature of the primary façade are used in results analysis.

There are four phases in this study: 1) literature review on EE calculation model for low cost housing in Indonesia; 2) developing EE calculation model based on Material Unit Analysis (MUA) by referring to Inventory of Carbon and Energy from the University of Bath and field calculation; 3) comparison of EE value of different types of low cost housing in Indonesia; 4) questionnaire and design approach to proposing strategies in mitigating environmental impacts by reducing EE value.

\section{Results and Analysis}

Comparison of the contour images of wind velocity inside the double skin façade reveals similar patterns of air movement. Figure 2 also shows that a little difference in the area near the primary skin due to variation in the space width. Arguably the narrower the space, 
which means the more air movement near the primary façade, will reduce more heat in the primary façade. It means more reduction in indoor air temperature. The average wind speed data in Figure 3 confirm this by showing that the $0.3 \mathrm{~m}$ façade has the highest average wind speed among the cases.

However, the temperature contour seems contradictory to the analysis of the wind velocity data. Temperature profiles in Figure 4 show higher value for the narrower width. It is confirmed by temperature data as shown by Figure 5a. If the air movement bring with it heat and reduce surface temperature, trend-line of the temperature is expected to mirroring the pattern of Figure 3 data. But, Figure 5a shows that temperature is lower in the wider double skin façade.

In order to have deeper understanding about the phenomenon, the analysis can use temperature increase rate and heat removal rate. Temperature increase rate is calculated from Eq. 3 and Table 1 sums the calculation results for each case. Meanwhile, the heat removal rate is derived from the data of volume flow rate at the outlets. Table 1 data asserts that heat removal rate is much lower than temperature increase rate. Moreover, a graph shown by Figure $5 \mathrm{~b}$ displays the difference of the four cases. It indicates that the wider the façade, the smaller the gap between heat gain and heat loss. This explains why a lower facade temperature resulted in the wider façade.
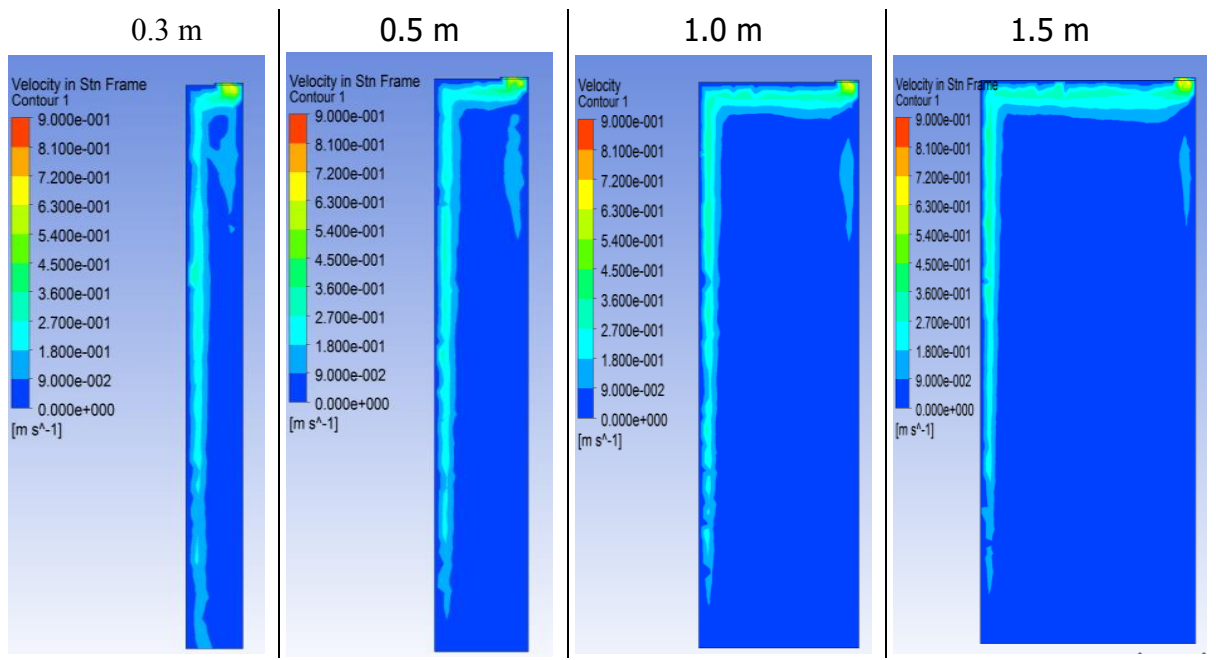

Fig. 2. Various width in the research and the result of velocity each.

Furthermore, the analysis can be extended to the relation between temperature and wind velocity to the width of the double skin façade. Figure 6 below exhibit the relation, by plotting wind velocity and temperature as a function of façade's width. Average wind velocity at the outlets make linear relation to the façade's width, while the average wind velocity inside the double skin façade make a 2 nd degree polynomial relation. More, average temperature inside the façade and average surface temperature of the primary skin façade, both have linear relation to the width. 


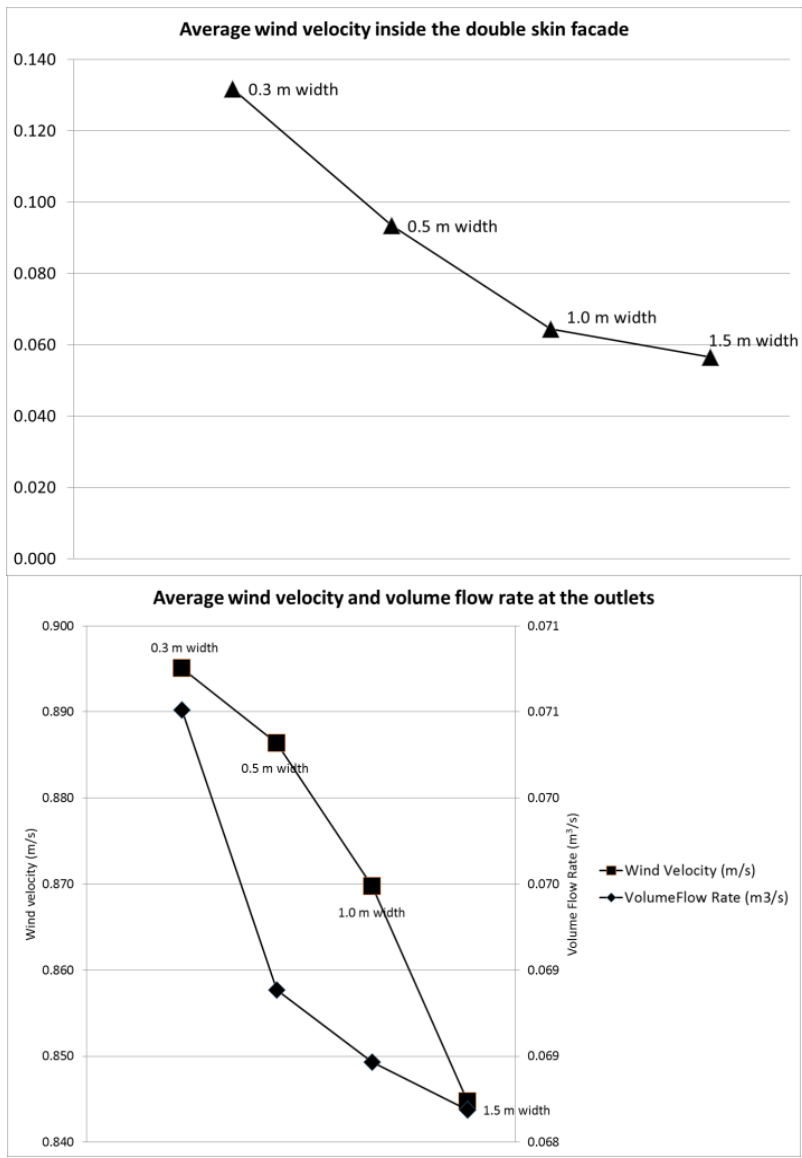

Fig. 3. Diagram that shows the average wind inside air gap DSF and volume rate at the outlet velocity in various width.

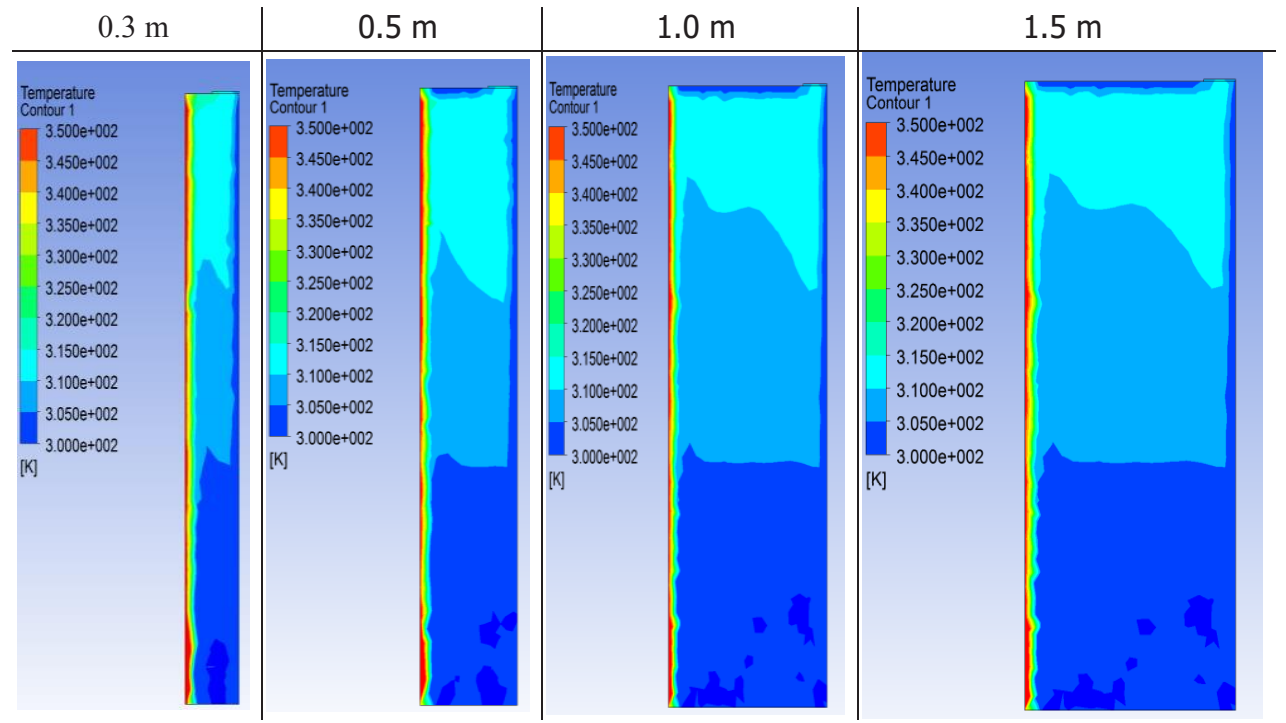

Fig. 4. Contour in various width in air gap of the double skin façade. 
Table 1. Effect comparison on setting configuration width in double skin facade

\begin{tabular}{|l|c|c|c|c|}
\hline & $\mathbf{0 . 3} \mathbf{~ m}$ width & $\mathbf{0 . 5} \mathbf{~ m}$ width & $\mathbf{1 . 0} \mathbf{~ m}$ width & $\mathbf{1 . 5} \mathbf{~ m}$ width \\
\hline Temperature increase rate (K/s) & 0.563 & 0.338 & 0.169 & 0.113 \\
\hline Percentage of temperature increase rate & $2.09 \%$ & $1.25 \%$ & $0.63 \%$ & $0.42 \%$ \\
\hline Percentage of heat removal rate & $0.023 \%$ & $0.013 \%$ & $0.006 \%$ & $0.004 \%$ \\
\hline
\end{tabular}

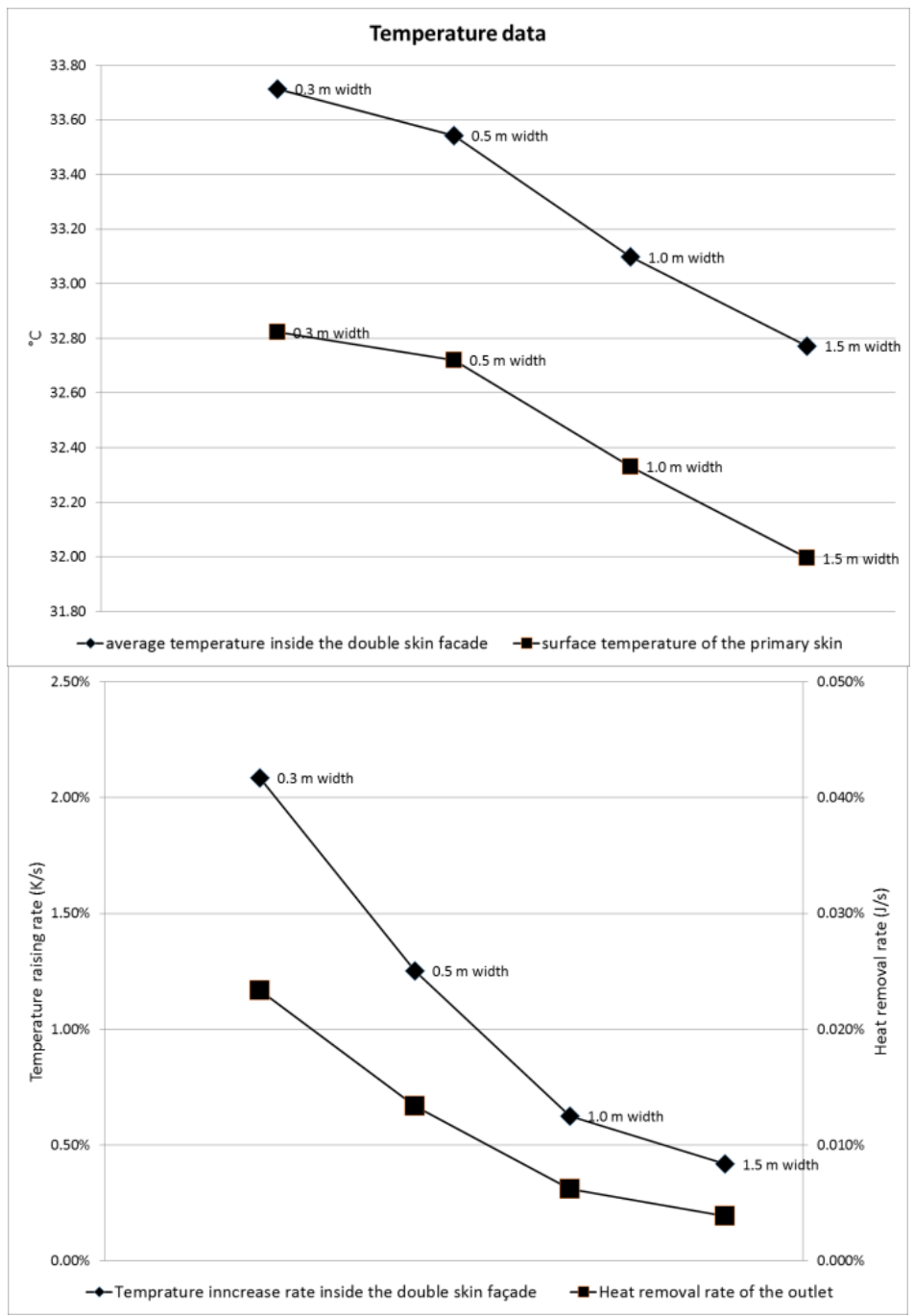

Fig. 5. Various width comparisons in diagram 


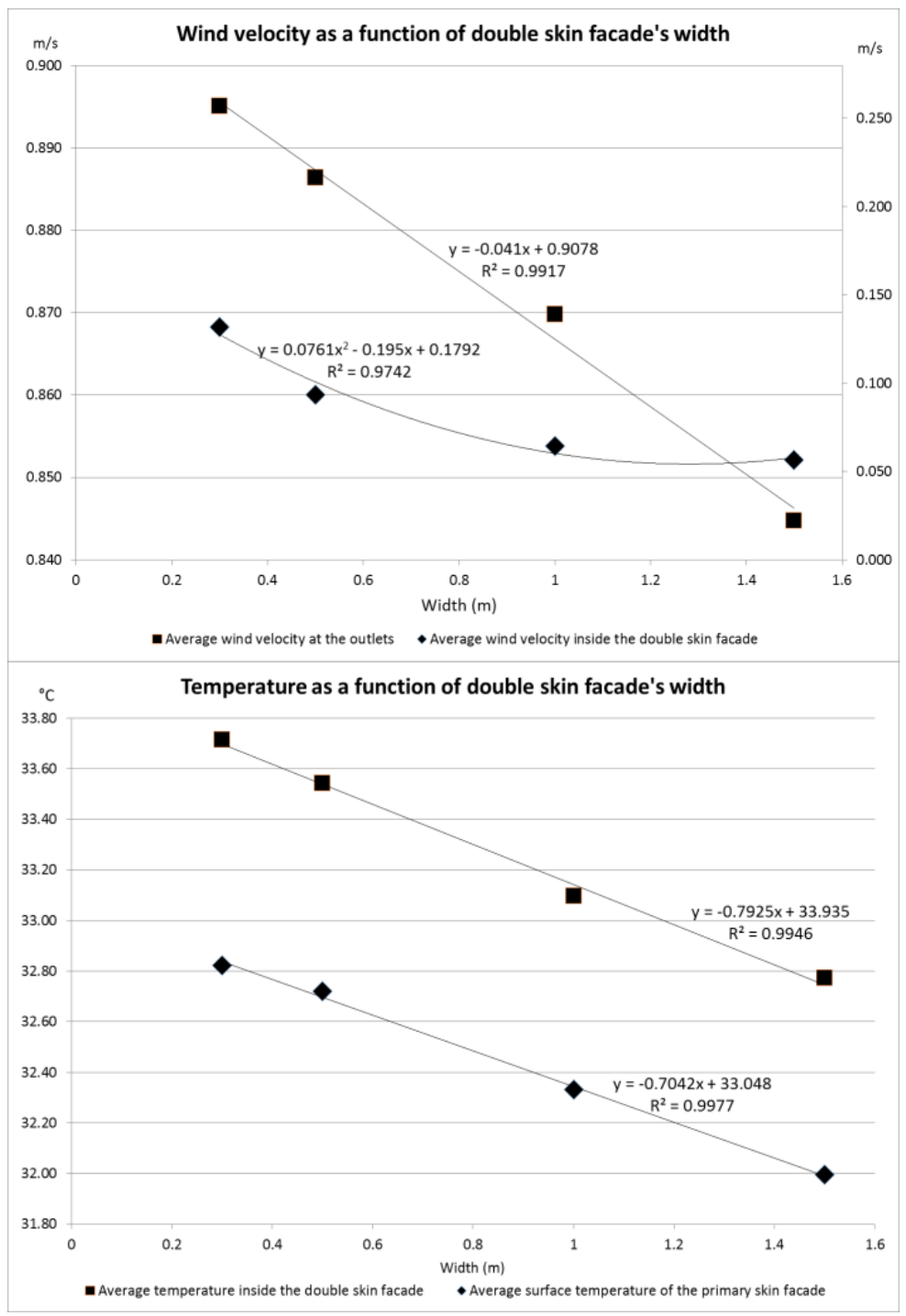

Fig. 6. The diagram shows the result by configure the air gap width in double skin facade

Acknowledgements. This research was funded by Indonesia Endowment Fund for Education (LPDP).

\section{References}

1. Baldinelli, G., "Building and Environment", 44 (6), 1107-1118 (2009)

2. Boake, T. M., Harrison, K., Collins, D., Chatham, A., \& Lee, R., "Understanding the General Principles of the Double Skin Façade System", 1-18 (2003)

3. F. Marques and M. Glo., "Energy Building”, 40, 1553-1559 (2008

4. Aziiz, A. D., Kusuma H.E., "11th International Symposium on Architectural Interchanges in Asia”, 1-5 (2016)

5. T. M. Boake, K. Harrison, D. Collins, A. Chatham, and R. Lee, "School of Architecture, University of Waterloo", 1-18 (2003) 
6. Darmayanty, N., "Institut Teknologi Bandung" (2014)

7. Lee, K., \& Lee, D., "Energy Procedia”, 78, 2851-2856 (2015)

8. Poirazis, H., \& Kragh, M., "Building Simulation”, 11, 1781-1788 (2009)

9. Barbosa, S., Ip, K., \& Southall, R., "Energy and Building”, 109, 397-406 (2015)

10. Iyati, Wasiska, "Institut Teknologi Bandung", (2012) 